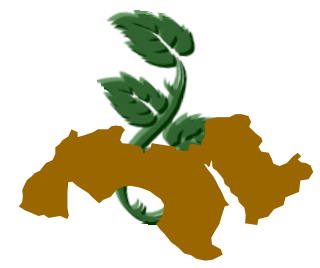

Arab Univ.

J. Agric. Sci.,

Ain Shams Univ.,

Cairo, 19(1), 163-170, 2011

\title{
CELLULASE PRODUCTION BY LOCAL BACTERIA ISOLATED FROM TAIF IN SAUDI ARABIA
}

\author{
Nasr $^{1}$, Sohair A.; Abeer A. Abozaid ${ }^{2}$; Nemmat A. Hussein ${ }^{3}$ \\ and Fawzia A. Al-salemi ${ }^{4}$
}

[11]

1- Dept. Microbiol., Fac. Agric., Ain Shams Univ., Egypt \& Biol. Dept., Fac. Sci., Taif Univ., Saudi Arabia

2- Agric. Res. Cen.,Cairo, Egypt \& Biol. Dept., Fac. Sci., Taif Univ., Saudi Arabia

3- Dept. Botany, Fac. Sci., Assiut Univ., Egypt \& Biol. Dept., Fac. Sci., Taif Univ., Saudi Arabia

4- Biol. Dept., Fac. Sci., Taif Univ., Saudi Arabia

Keywords: Cellulase production, Bacillus sp.

\section{ABSTRACT}

Among 20 bacterial isolates isolated from the soil of El-hawia, El-hada, El-kaym and Karwa in Taif governorate in Saudi Arabia,two isolates had high efficacy in producing cellulase enzyme. They belonged to genus Bacillus (Bacillus 8 \& 17). Some factors such as carbon source and wheat bran as a raw material, nitrogen source, $\mathrm{pH}$ and incubation temperature were investigated. Results indicated that CMC and cellulose were the most effective as they enhanced cellulases production Sodium nitrate and ammonium chloride were the best nitrogen sources for cellulases production. Initial pH 7.0 was found to be optimal for growth and cellulase production. Incubation temperatures at $25-40^{\circ} \mathrm{C}$ achieved high cellulases production by the two isolates.

\section{INTRODUCTION}

Cellulose biodegradation by cellulases and cellulosomes, produced by numerous microorganisms, represents a major carbon flow from fixed carbon sinks to atmospheric $\mathrm{CO}_{2}$ (Falkowski et al 2000; Melillo et al 2002 and Berner, 2003), which is very important in several agricultural and waste treatment processes (Angenent et al 2004; Das \& Singh, 2004; Haight, 2005 and Schloss et al 2005), and could be widely used to produce sustainable biobased products and bioenergy from less costly renewable lignocellulosic material to replace depleting fossil fuels and reduce environ- mental pollution (Mohanty et al 2000; Mielenz, 2001; Galbe and Zacchi, 2002; Hoffert et al 2002; Lynd et al 2002; Wyman, 2003; Kamm and Kamm, 2004; Demain et al 2005; Moreira, 2005 and Reddy \& Yang, 2005).

Complete enzymatic hydrolysis of enzyme requires synergistic action of 3 types of enzymes, namely cellobiohydrolase $(\mathrm{CBH})$, endoglucanase (EG) or carboxymethycellulase (CMCase) and $\beta$ glucosidases (Bhat, 2000). Cellulases are used in the textile industry for cotton softening and denim finishing; in laundry detergents for color care, cleaning and anti-deposition; in the food industry for mashing; in the pulp and paper industries for deinking, drainage improvement and fiber modification and they are even used for pharmaceutical applications (Kirk et al., 2002 and Cherry \& Fidantsef, 2003).

This work aimed to isolate some bacterial isolates, showed high efficacy in producing cellulases enzymes from Taif in Saudi Arabia and to find out some factors enhancing the cellulases production.

\section{MATERIALS AND METHODS}

\section{Soil samples}

Calcareous soil samples were obtained from El-hawia, El-hada, El-Kaym and Karwa in Taif governorate in Saudi Arabia for isolation of bacterial isolates.

(Taif area found in Eastern province of Saudi Arabia, the landscape between Makkah and Taif, is littered with high mountains). 


\section{Bacterial isolates}

Twenty isolates were obtained from the soil of Taif governorate in Saudi Arabia.

\section{Media used}

Medium (1): Nutrient agar (Difco Manual, 1984). It was used for growth and maintenance of bacteria It has the following composition: $(\mathrm{g} / \mathrm{L})$ Peptone 5.0, Beef extract 3.0, Agar agar 20, Distilled water $1000 \mathrm{ml}$ and $\mathrm{pH} 7.0$.

Medium (2): Carboxymethyl cellulose medium (Ray et al 2007). It was used for cellulase production. It has the following composition: ( $\mathrm{g} / \mathrm{L}$ ) $\mathrm{CMC} 10.0, \mathrm{KH}_{2} \mathrm{PO}_{4} 4.0, \mathrm{Na}_{2} \mathrm{HPO}_{4} 4.0, \mathrm{MgSO}_{4} .7 \mathrm{H}_{2} \mathrm{O}$ $0.2, \mathrm{CaCl}_{2} .2 \mathrm{H}_{2} \mathrm{O} 0.001$, $\mathrm{FeSO}_{4} .7 \mathrm{H}_{2} \mathrm{O} 0.004$, Tryptone 2.0, Distilled water $1000 \mathrm{ml}$ and $\mathrm{pH}$ 7.0.

The above medium was modified by replacing glucose in the basal medium with addition of CMC in concentration of $10 \mathrm{~g} / \mathrm{L}-1$ as a substrate to produce cellulase enzyme.

\section{Standard inoculum}

For preparation of standard inoculum, both selected isolates of Bacillus were cultivated on nutrient broth individually at $30 \stackrel{\circ}{\circ}$ for $24 \mathrm{~h}$ where an average viable count of $3.5-4.3 \times 10^{6}$ cells $/ \mathrm{ml}$ culture broth was obtained. This was used as an inoculum for the production medium.

\section{Fermentation}

It was carried out in $250 \mathrm{ml}$ Erlenmeyer flask containing $100 \mathrm{ml}$ medium No. (2) for supplemented with $\mathrm{CMC}$ as a substrate to produce cellulase enzyme. The flasks were sterilized at $121^{\circ} \mathrm{C}$ for 15 min. The flasks were inoculated with $3 \%$ standard inoculum $(\mathrm{v} / \mathrm{v})$ transferred to the production medium, and then incubated on a rotary shaker (150 rpm). The broth after cultivation was used for enzyme studies. (Dien et al 2006).

\section{Enzyme assays}

\section{Plate enzyme assay screening}

At the end of the incubation, the agar medium was flooded with an aqueous solution of Congo red $(1 \% \mathrm{w} / \mathrm{v})$ for 15 minutes. The Congo red solution was then poured off, and the plates were further treated by flooding with $1 \mathrm{M} \mathrm{NaCl}$ for 15 minutes. The formation of a clear zone of hydroly- sis indicated cellulose degradation. The ratio of the clear zone diameter to colony diameter was measured in order to select for the highest cellulase activity producer. The largest ratio was assumed to contain the highest activity (Howard et al 2003 \& Ariffin et al 2006).

\section{Carboxymethyl cellulose (CMC ase) activity}

CMCase activity was assayed using a method described by Mandels and Weber (1969). The activity was estimated using $1 \%$ solution of carboxymethlycellulose (CMC) in $0.05 \mathrm{M}$ citrate buffer $(\mathrm{pH} 4.8)$ as substrate. The reaction mixture contained $1 \mathrm{ml}$ citrate buffer, $0.5 \mathrm{ml}$ of substrate solution and $0.5 \mathrm{ml}$ of suitably diluted enzyme solution. The reaction was carried out at $50^{\circ} \mathrm{C}$ for $30 \mathrm{~min}$. One unit of CMCase activity was expressed as $1 \mu$ mol of glucose liberated per $\mathrm{ml}$ enzyme per minute.

\section{Filter-paperase (FPase) activity}

The activity of FPase was assayed according to the method explained by Mandels and Weber (1969). This method is similar to the CMCase assay method, but the substrate was Whatman No. 1 filter paper strip $(1 \times 6 \mathrm{~cm}$ ) soaked in $1 \mathrm{ml} 0.05 \mathrm{M}$ sodium citrate buffer $(\mathrm{pH} 4.8)$. The samples were incubated with $0.5 \mathrm{ml}$ enzyme solution at $50^{\circ} \mathrm{C}$ for $1 \mathrm{~h}$. One unit of $\mathrm{F}$ Pase activity was determined as $1 \mu \mathrm{mol}$ of glucose liberated per $\mathrm{ml}$ enzyme per minute.

\section{$\beta$-Glucosidase activity}

One-tenth $\mathrm{ml}$ of the culture supernatant was incubated with $0.5 \mathrm{ml}$ of $0.05 \mathrm{M}$ acetate buffer $(\mathrm{pH} 5)$ containing $2.5 \mathrm{mg}$ cellobiose. After incubation at $50^{\circ} \mathrm{C}$ for $10 \mathrm{~min}$, the glucose released was measured by the glucose oxidase peroxidase method (Zaldívar et al 2001)

\section{Determination of sugars}

The total amount of non-reducing sugars (as cellulose) was determined by the glucose oxidase peroxidase kit from (BIO-ADWIC) EL NASR PHARMACEUTICAL CHEMICALS Co. (Egypt).

\section{Effect of different carbon sources}

The appropriate carbon source was selected by replacing the original carbon substrate of the basal medium with equivalent carbon amount of each of the tested carbon sources (Glucose, Carboxymethycellulose, Cellobiose and Cellulose). 


\section{Pretreatment of wheat bran (raw material)}

Wheat bran was pretreated with $4 \%$ solution of sodium hydroxide $(2000 \mathrm{ml} / 100 \mathrm{~g}$ substrate), autoclaved at $121^{\circ} \mathrm{C}$ for $30 \mathrm{~min}$. The material recovered by filtration was washed with distilled water until neutralilty $(\mathrm{pH} 7.0)$ and dried at $65^{\circ} \mathrm{C}$ to constant weight.

\section{Effect of different nitrogen sources}

To detect the proper nitrogen source for cellulase production by selected isolates, the prescribed nitrogen source of the fermentation medium was replaced by equivalent nitrogen amount of each of the tested organic [Yeast extract, Peptone, Urea] and inorganic nitrogen sources $\left[\mathrm{NaNO}_{3}\right.$, $\left.\mathrm{NH}_{4} \mathrm{Cl} \&\left(\mathrm{NH}_{4}\right)_{2} \mathrm{SO}_{4}\right]$.

\section{Effect of initial pH}

Five values of $\mathrm{pH}$ ranged between 5.0 and 9.0 were chosen for studying their effects on cellulase enzyme to select the most suitable $\mathrm{pH}$ of the production medium.

\section{Effect of incubation temperature}

To determine the optimum temperature for cellulase production, fermentation was carried out at various temperatures in the range of 20 to $40^{\circ} \mathrm{C}$ with $5^{\circ} \mathrm{C}$ interval.

\section{RESULTS AND DISCUSSION}

\section{Isolation of cellulase producing Bacteria}

A number of 20 bacterial isolates were obtained from different sources of soil from Taif governorate in Saudi Arabia. Screening of bacterial isolates for cellulases activities was conducted by using Congo red test as a preliminary study for selecting the cellulases producers. After 72 hours of incubation, all 20 bacterial isolates showed signs of growth on CMC agar and demonstrated positive results in the Congo red test. Since the sole carbon source in CMC agar was carboxymethylcellulose $(\mathrm{CMC})$, therefore the result of the test was a strong evident that cellulase was produced in order to degrade cellulose. They belonged to two genera Bacillus and Micrococcus. Data presented in Table (1) clearly show that $\mathrm{Ba}$ cillus sp. (8) and Bacillus sp. (17) were the most efficient isolates selected according to the high ratio of clear zone diameter to colony diameter being 5.75 and 5.4 for Bacillus sp. (8) and Bacillus sp. (17), respectively. These results are on line with Horikoshi, 1999 and Ozawa et al 2001 who found that the alkaliphilic properties of cellulases produced by Bacillus spp. due to the possible application of these enzymes in the detergent industry .Also, Nakamura \& Kappamura (1982) and Immanuel et al (2006) studied the celluloytic property of bacterial species like Pseudomonas, Cellulomonas, Bacillus, Micrococcus and Cellovibrio spp.

An experiment was carried out to investigate the effect of different carbon sources such as glucose, carboxymethycellulose (CMC), cellobiose, cellulose and wheat bran (as a raw material) on the production of cellulase enzyme extracted by isolates of Bacillus sp.(8) and Bacillus sp (17). Five carbon sources were used as shown in Table (2). Data presented in Table (2) clearly show that medium containing cellulose gave the highest yield of cellulase activity being $2.912 \mathrm{U} / \mathrm{ml}$ of CMCase, but medium containing CMC gave the highest FPase and $\beta$ - glucosidases being $0.923 \& 0.542$ $\mathrm{U} / \mathrm{ml}$ by Bacillus sp.(8). While, the medium containing CMC gave the highest CMCase and $\beta$ - glucosidases being $1.978 \& 0.642 \mathrm{U} / \mathrm{ml}$, respectively by Bacillus sp (17). Regarding the use of raw material as a sole source of carbon, the yield of CMCase enzyme was highest on wheat bran being $0.761 \& 0.983 \mathrm{U} / \mathrm{ml}$ by Bacillus sp.(8) and Bacillus sp (17), respectively.

To evaluate the effect of nitrogen source on cellulase formation, the nitrogen source in the basal medium was replaced by different nitrogen sources. Data revealed that the supplementation of organic and inorganic nitrogen sources stimulated the cellulase yield and activity.

Results recorded in Table (3) clearly indicated that the sources of nitrogen greatly affected the production of cellulase. Sodium nitrates was the best nitrogen source for Bacillus sp. (8) giving $3.197 \mathrm{U} / \mathrm{ml}$ of CMCase.

Ammonium chloride, however, gave the highest figures showing $0.923 \mathrm{U} / \mathrm{ml}$ of FPase and 1.398 $\mathrm{U} / \mathrm{ml}$ of $\beta$-glucosidases. Sodium nitrate also showed the best nitrogen source for Bacillus sp. (17) giving $2.594 \mathrm{U} / \mathrm{ml}$ of CMCase. Peptone as organic nitrogen source gave the highest values of cellulases enzymes being $2.190 \mathrm{U} / \mathrm{ml}$ of FPase and $2.902 \mathrm{U} / \mathrm{ml}$ of $\beta$-glucosidases.

These results are on line with Krishna (1999) and Osono \& Takeda (2001) who reported that the source of nitrogen should be inorganic for better results. 
Table 1. Hydrolysis ratio of carboxymethy cellulose (CMC) by bacterial isolates incubated at $28^{\circ} \mathrm{C}$ for 72 hours

\begin{tabular}{|c|c|c|c|}
\hline Bacterial isolates & $\begin{array}{l}\text { Growth diameter } \\
\qquad(\mathrm{cm})\end{array}$ & $\begin{array}{l}{ }^{*} \text { Cellulolysis diameter } \\
\qquad(\mathrm{cm})\end{array}$ & $\begin{array}{l}{ }^{* *} \text { Cellulolysis } \\
\text { ratio }\end{array}$ \\
\hline Bacillus sp. (1) & 0.8 & 2.7 & 3.38 \\
\hline Bacillus sp. (2) & 0.7 & 2.0 & 2.86 \\
\hline Micrococcus sp. (3) & 1.2 & 1.8 & 1.5 \\
\hline Micrococcus sp. (4) & 0.6 & 1.5 & 2.5 \\
\hline Micrococcus_sp. (5) & 0.5 & 1.3 & 2.6 \\
\hline Bacillus sp. (6) & 0.5 & 2.0 & 4.0 \\
\hline Bacillus sp. (7) & 0.6 & 1.8 & 3.0 \\
\hline Bacillus sp. (8) & 0.4 & 2.3 & 5.75 \\
\hline Bacillus sp. (9) & 0.6 & 2.1 & 3.5 \\
\hline Micrococcus sp. (10) & 0.9 & 1.9 & 2.11 \\
\hline Bacillus sp. (11) & 0.8 & 1.9 & 2.38 \\
\hline Bacillus sp. (12) & 0.6 & 1.3 & 2.17 \\
\hline Bacillus sp. (13) & 0.6 & 2.1 & 3.5 \\
\hline Micrococcus sp. (14) & 0.5 & 1.6 & 3.2 \\
\hline Bacillus sp. (15) & 0.7 & 1.7 & 2.43 \\
\hline Micrococcus sp. (16) & 0.6 & 2.0 & 3.33 \\
\hline Bacillus sp. (17) & 0.5 & 2.7 & 5.40 \\
\hline Bacillus sp. (18) & 0.7 & 1.7 & 2.43 \\
\hline Bacillus sp. (19) & 0.5 & 2.5 & 5.0 \\
\hline Micrococcus sp. (20) & 0.5 & 2.3 & 4.6 \\
\hline
\end{tabular}

Table 2. Effect of carbon sources on production of cellulase enzyme by Bacillus sp. (8) and Bacillus sp. (17) using shake flasks (150 rpm) as a batch culture technique

\begin{tabular}{|c|c|c|c|c|c|c|c|c|}
\hline \multirow{3}{*}{$\begin{array}{c}\text { Different } \\
\text { carbon sources }\end{array}$} & \multicolumn{4}{|c|}{ Bacillus sp. (8) } & \multicolumn{4}{|c|}{ Bacillus sp.(17) } \\
\hline & \multirow{2}{*}{$\begin{array}{l}\text { Biomass } \\
\mathrm{g} / 100 \mathrm{ml}\end{array}$} & \multicolumn{3}{|c|}{ Cellulase Activity (U) } & \multirow{2}{*}{$\begin{array}{l}\text { Biomass } \\
\mathrm{g} / 100 \mathrm{ml}\end{array}$} & \multicolumn{3}{|c|}{ Cellulase Activity (U) } \\
\hline & & CMCase & FPase & $\begin{array}{c}\beta- \\
\text { glucosidases }\end{array}$ & & CMCase & FPase & $\begin{array}{c}\beta- \\
\text { glucosidases }\end{array}$ \\
\hline Glucose & 0.170 & 1.133 & 0.682 & 0.344 & 0.132 & 2.071 & 0.138 & 0.099 \\
\hline $\begin{array}{l}\text { Carboxymethy } \\
\text { cellulase } \\
\text { (CMC) (Control) }\end{array}$ & 0.254 & 1.653 & 0.923 & 0.542 & 0.197 & 1.978 & 0.793 & 0.642 \\
\hline Cellobiose & 0.259 & 1.363 & 0.103 & 0.081 & 0.221 & 0.532 & 0.163 & 0.157 \\
\hline Cellulase & 0.342 & 2.912 & 0.450 & 0.196 & 0.517 & 0.534 & 0.993 & 0.179 \\
\hline Wheat bran & 0.132 & 0.761 & 0.093 & 0.064 & 0.118 & 0.983 & 0.197 & 0.123 \\
\hline
\end{tabular}


Table 3. Effect of nitrogen sources on the production of cellulase enzyme by Bacillus sp. (8) and Bacillus sp. (17) using shake flasks (150 rpm) as a batch culture technique

\begin{tabular}{|c|c|c|c|c|c|c|c|c|}
\hline \multirow{3}{*}{$\begin{array}{l}\text { Different } \\
\text { Nitrogen } \\
\text { Sources }\end{array}$} & \multicolumn{4}{|c|}{ Bacillus sp. (8) } & \multicolumn{4}{|c|}{ Bacillus sp. (17) } \\
\hline & \multirow{2}{*}{$\begin{array}{c}\text { Biomass } \\
\mathrm{g} / 00 \mathrm{ml}\end{array}$} & \multicolumn{3}{|c|}{ Cellulase Activity (U) } & \multirow{2}{*}{$\begin{array}{c}\text { Biomass } \\
\text { g I 00ml } \\
\text { FPase }\end{array}$} & \multicolumn{3}{|c|}{ Cellulase Activity (U) } \\
\hline & & CMCase & FPase & $\begin{array}{c}\text { B- } \\
\text { glucosidases }\end{array}$ & & CMCase & FPase & $\begin{array}{c}\text { B- } \\
\text { glucosidases }\end{array}$ \\
\hline $\begin{array}{l}\text { Yeast } \\
\text { extract }\end{array}$ & 0.131 & 2.618 & 0.551 & 1.287 & 0.201 & 1.380 & 2.015 & 2.227 \\
\hline Peptone & 0.099 & 1.012 & 0.198 & 1.364 & 0.231 & 1.570 & 2.190 & 2.902 \\
\hline Urea & 0.199 & 0.273 & 0.229 & 0.292 & 0.194 & 2.174 & 0.777 & 0.651 \\
\hline $\mathrm{NaNO}_{3}$ & 0.136 & 3.197 & 0.353 & 0.446 & 0.198 & 2.594 & 0.809 & 0.748 \\
\hline $\mathrm{NH}_{4} \mathrm{Cl}$ & 0.098 & 0.434 & 0.923 & 1.398 & 0.138 & 1.178 & 0.527 & 0.442 \\
\hline$\left(\mathrm{NH}_{4}\right)_{2} \mathrm{SO}_{4}$ & 0.254 & 1.653 & 0.200 & 0.545 & 0.199 & 1.978 & 0.813 & 0.643 \\
\hline
\end{tabular}

Table 4. Effect of initial pH on the production of cellulase enzyme by Bacillus sp. (8) and Bacillus sp. (17) using shake flasks (150 rpm) as a batch culture technique

\begin{tabular}{|c|c|c|c|c|c|c|c|c|}
\hline \multirow{3}{*}{ Initial pH } & \multicolumn{5}{|c|}{ Bacillus sp.(8) } & \multirow{2}{*}{\multicolumn{3}{|c|}{$\begin{array}{c}\text { Bacillus sp. (17) } \\
\text { Cellulase Activity }(U)\end{array}$}} \\
\hline & \multirow{2}{*}{$\begin{array}{l}\text { Biomass } \\
\mathrm{g} / 100 \mathrm{ml}\end{array}$} & \multicolumn{3}{|c|}{ Cellulase Activity (U) } & \multirow{2}{*}{$\begin{array}{l}\text { Biomass } \\
\mathrm{g} / 100 \mathrm{ml}\end{array}$} & & & \\
\hline & & CMCase & FPase & $\begin{array}{l}\beta \text { - } \\
\text { glucosidases }\end{array}$ & & CMCase & FPase & $\begin{array}{l}\beta \text { - } \\
\text { glucosidases }\end{array}$ \\
\hline 5.0 & 0.119 & 1.132 & 1.176 & 0.196 & 0.077 & 0.463 & 0.131 & 0.098 \\
\hline 6.0 & 0.188 & 1.271 & 0.534 & 0.313 & 0.105 & 0.193 & 0.151 & 0.139 \\
\hline 7.0 & 0.254 & 1.652 & 0.912 & 0.592 & 0.197 & 1.978 & 0.793 & 0.642 \\
\hline 8.0 & 0.203 & 1.093 & 0.463 & 0.273 & 0.117 & 0.867 & 0.298 & 0.121 \\
\hline 9.0 & 0.050 & 0.615 & 0.239 & 0.099 & 0.053 & 0.751 & 0.233 & 0.111 \\
\hline
\end{tabular}

Table 5. Effect of incubation temperature on the production of cellulase enzyme by Bacillus sp. (8) and Bacillus sp. (17) using shake flasks (150 rpm) as a batch culture technique

\begin{tabular}{|c|c|c|c|c|c|c|c|c|}
\hline \multirow{3}{*}{$\begin{array}{l}\text { Incubation } \\
\text { temperature } \\
{ }^{\circ} \mathrm{C}\end{array}$} & \multicolumn{4}{|c|}{ Bacillus sp. (8) } & \multicolumn{4}{|c|}{ Bacillus sp. (17) } \\
\hline & \multirow{2}{*}{$\begin{array}{l}\text { Biomass } \\
\mathrm{g} / 100 \mathrm{ml}\end{array}$} & \multicolumn{3}{|c|}{ Cellulase Activity (U) } & \multirow{2}{*}{$\begin{array}{l}\text { Biomass } \\
\mathrm{g} / 100 \mathrm{ml}\end{array}$} & \multicolumn{3}{|c|}{ Cellulase Activity (U) } \\
\hline & & CMCase & FPase & $\begin{array}{c}\beta- \\
\text { glucosidases }\end{array}$ & & CMCase & FPase & $\begin{array}{c}\beta- \\
\text { glucosidases }\end{array}$ \\
\hline 20 & 0.093 & 0.987 & 0.318 & 0.166 & 0.123 & 1.009 & 0.268 & 0.102 \\
\hline 25 & 0.135 & 1.119 & 0.712 & 0.381 & 0.148 & 1.321 & 0.491 & 0.296 \\
\hline 30 & 0.242 & 1.593 & 1.002 & 0.532 & 0.198 & 1.877 & 0.832 & 0.651 \\
\hline 35 & 0.253 & 1.507 & 0.470 & 0.188 & 0.109 & 1.060 & 0.450 & 0.235 \\
\hline 40 & 0.189 & 0.970 & 0.135 & 0.092 & 0.091 & 0.692 & 0.374 & 0.112 \\
\hline
\end{tabular}


An increase in cellulase activity was observed when enriching medium with $1 \%$ ammonium sulphate, but further increase in the concentration did not improve cellulase production. Also, Rajoka (2004) reported that $\mathrm{KNO}_{3}$ and $\mathrm{NH}_{4} \mathrm{NO}_{3}$ were the best nitrogen sources for cellulase synthesis in Cellulomonas flavigena.

In Table (4), five values of $\mathrm{pH}$ ranged between 5.0 and 9.0 were chosen for studying their effects on cellulase production by Bacillus sp.(8) and Bacillus sp. (17). The highest yields of cellulase activity at $\mathrm{pH} 7.0$ were $1.652 \& 1.978 \mathrm{U} / \mathrm{ml}$ of CMCase extracted by isolates Bacillus sp.(8) and Bacillus sp. (17), respectively. The respective values for FPase were $0.912 \& 0.793 \mathrm{U} / \mathrm{ml}$ and for $\beta$ glucosidases were $0.592 \& 0.642 \mathrm{U} / \mathrm{ml}$ by Bacillus sp. (8) and Bacillus sp. (17), respectively.

These results are on line with Ray et al (2007) who found that $\mathrm{pH} 7.0-7.5$ was more suitable for optimization of cellulase production by Bacillus subtilis and Bacillus circulans.

An experiment was constructed to find out the effect of different degrees of incubation temperatures ranged from 20 to $40^{\circ} \mathrm{C}$ with $5^{\circ} \mathrm{C}$ interval on cellulase production by Bacillus sp.(8) and Bacillus sp. (17). Results in Table (5) show that incubation on different degrees of temperatures from 20 to $40^{\circ} \mathrm{C}$ achieved high cellulase production .These results are in agreement with Immanuel et al (2006) who recorded that endoglucanase activity in Cellulomonas, Bacillus and Micrococcus sp. reached maximum at the neutral $\mathrm{pH}$ and $40^{\circ} \mathrm{C}$.

In the present study, it could be concluded that carbon and nitrogen sources, $\mathrm{pH}$ values and incubation temperatures play an important role in the production of cellulase activity by local bacilli isolated from Taif in Saudi Arabia.

Acknowledgement: The authors are pleased to acknowledge Taif University, Saudi Arabia for supporting this work during the project No.710-431- 1 in Faculty of Science (women).

\section{REFERENCES}

Angenent, L.T.; K. Karim; M.H. Al-Dahhan; B.A. Wrenn and R. Domiguez-Espinosa (2004). Production of bioenergy and biochemicals from industrial and agricultural wastewater. Trends Biotechnol., 22(9): 477-485.

Ariffin, H.; N. Abdullah; M.S. Umi Kalsom; Y. Shirai and M.A. Hassan (2006). Production and characterisation of cellulase by Bacillus pumilus EB3. Int. J. of Eng. \& Technol., 3(1): 47-53.

Berner, R.A. (2003). The long-term carbon cycle, fossil fuels and atmospheric composition. Nature, 426 (6964): 323- 326.

Bhat, M.K. (2000). Cellulases and related enzymes in biotechnology. Biotech. Adv., 18(5): 355-383.

Cherry, J.R. and A.L. Fidantsef (2003). Directed evolution of industrial enzymes: an update. Curr. Opin. Biotechnol., 14(4): 438-443.

Das, H. and S.K. Singh (2004). Useful byproducts from cellulosic wastes of agriculture and food industry-a critical appraisal. Crit. Rev. Food Sci. Nutr., 44(2): 77-89.

Demain, A.L.; M. Newcomb and J.H.D. Wu (2005). Cellulase, clostridia, and ethanol. Microbiol. Mol. Biol. Rev., 69(1): 124-154.

Dien, B.S.; X.L. Li; L.B. Iten; D.B. Jordan; N.N. Nichols; P.J. O'Bryan and M.A. Cotta (2006). Enzymatic saccharification of hotwater pretreated corn fiber for production of monosaccharides. Enzyme \& Microbial Technol., 39(55): 1137-1144.

Difco Manual (1984). Dehydrated Culture Media and Reagents for Microbiology. $10^{\text {th }} \mathrm{Ed}$. Difco. Laboratories, Detroit, U.S.A.

Falkowski, P.; R.J. Scholes; E. Boyle; J. Canadell; D. Canfield; J. Elser; N. Gruber; K. Hibbard; P. Högberg; S. Linder; F.T. Mackenzie; B. Moore III; T. Pedersen; Y. Rosenthal; S. Seitzinger; V. Smetacek and W. Steffen (2000). The global carbon cycle: a test of our knowledge of earth as a system. Science, 290 (5490):291-296.

Galbe, M. and G. Zacchi (2002). A review of the production of ethanol from softwood. Appl. Microbiol. Biotechnol., 59(6): 618-628.

Haight, M. (2005). Assessing the environmental burdens of anaerobic digestion in comparison to alternative options for managing the biodegradable fraction of municipal solid wastes. Water Sci. Technol., 52: 553-559.

Hoffert, M.I.; K. Caldeira; G. Benford; D.R. Criswell; C. Green; H. Herzog; A.K. Jain; H.S. Kheshgi; K.S. Lackner; J.S. Lewis; H.D. Lightfoot; W. Manheimer; J.C. Mankins; M.E. Mauel; L.J. Perkins; M.E. Schlesinger; T. Volk and T.M.L. Wigley (2002). Advanced technology paths to global climate stability: energy for a greenhouse planet. Science, 298(5595): 981-987. 
Horikoshi, K. (1999). Alkaliphiles: some applications of their products for biotechnology. Microbiol. \& Mol. Biol. Rev., 63(4): 735-750.

Howard, R.L.; P. Masoko and E. Abotsi (2003). Enzyme activity of a Phanerochaete chrysosporium cellobiohydrolase (CBHI.1) expressed as a heterologous protein from Escherichia coli. African J. Biotechnol., 2 (9): 296-300.

Immanuel, G.; R. Dhanusa; P. Prema and A. Palavesam (2006). Effect of different growth parameters on endoglucanase enzyme activity by bacteria isolated from coir retting effluents of estuarine environment. Int. J. Environ. Sci. Tech. 3(1): 25-34.

Kamm, B. and M. Kamm (2004). Principles of biorefineries. Appl. Microbiol. Biotechnol., 64(2):137-145.

Kirk, O.; T.V. Borchert and C.C. Fuglsang (2002). Industrial enzyme applications. Curr. Opin. Biotechnol., 13(4): 345-351.

Krishna, C. (1999). Production of bacterial cellulases by solid state bioprocessing of banana wastes. Bioresou. Technol., 69(3): 231- 239.

Lynd, L.R; P.J. Weimer; W.H. van Zyl and I.S. Pretorius (2002). Microbial celluluose utilization: Fundamentals and Biotechnology. Microbial. Mol. Biol. Rev., 66(3): 506-577.

Mandels, M. and J. Weber (1969). The production of cellulases. In: Cellulases and Their Applications. pp. 391-414., Hajny, G.J. \& E.T. Reese (eds), American Chemical Society, Washington DC.

Melillo, J.M.; P.A. Steudler; J.D. Aber; K. Newkirk; H. Lux; F.P. Bowles; C. Catricala; A. Magill; T. Ahrens and S. Morrisseau (2002). Soil warming and carbon-cycle feedbacks to the climate system. Science, 298 (5601): 2173-2176.

Mielenz, J.R. (2001). Ethanol production from biomass: technology and commercialization status. Curr. Opin. Microbiol., 4(3): 324-329.

Mohanty, A.K.; M. Misra and G. Hinrichsen (2000). Biofibres, biodegradable polymers and biocomposites: an overview. Macromol. Mater Eng., 276-277(1): 1-24.
Moreira, N. (2005). Growing expectations: new technology could turn fuel into a bumper crop. Sci. News Online, 168 (14): 209-224.

Nakamura, K. and K. Kappamura (1982). Isolation and identification of crystalline cellulase hydrolyzing bacterium and its enzymatic properties. J. Ferment. Technol., 60(4): 343-348.

Osono, T. and H. Takeda (2001). Effects of organic chemical quality and mineral nitrogen addition on lignin and holocellulose decomposition of beech leaf litter by Xylaria sp. Eur. J. Soil Biol., 37: 17-23.

Ozawa, T.; Y. Hakamada; Y. Hatada; T. Kobayashi; T. Shirai and S. Ito (2001). Thermostabilization by replacement of specific residues with lysine in a Bacillus alkaline cellulase: building a structural model and implication of newly formed double intrahelical salt bridges. Protein Eng., 14(7): 501-504.

Rajoka, M.I. (2004). Influence of various fermentation variables on exo-glucanase production in Cellulomonas flavigena. Electr. J. of Biotechnol., 7(3): 256-263.

Ray, A.K.; A. Bairagi; K.S. Ghosh and S.K. Sen (2007). Optimization of fermentation conditions for cellulose production by Bacillus subtilis CY5 and Bacillus circulans TP3 isolated from fish gut. Acta, Ichthyologica ET Piscatoria, 37(1): 47-53.

Reddy, N. and Y. Yang (2005). Biofibers from agricultural by products for industrial applications. Trends Biotechnol., 23(1): 22-27.

Schloss, P.D.; A.G. Hay; D.B. Wilson; J.M. Gossett and L.P. Walker (2005). Quantifying bacterial population dynamics in compost using $16 \mathrm{~S}$ rRNA gene probes. Appl. Microbiol. Biotechnol., 66: 457-463.

Wyman, C.E. (2003). Potential synergies and challenges in refining cellulosic biomass to fuels, chemicals, and power. Biotechnol. Prog., 19(2): 254-262.

Zaldivar, M.; J.C. Velásquez; I. Contreras and L. M. Pérez (2001). Trichoderma aureoviride T121 , a mutant with enhanced production of lytic enzymes: its potential use in waste cellulose degradation and/or biocontrol. Elect. J. of Biotechnol., 4(3): 160-168. 